\title{
Growth hormone on ovarian morphology of lambaris (Astyanax bimaculatus) after induced spawning
}

\author{
Lucas Marcon ${ }^{1,2,3}$ (D) Vivian Rocha Freitas ${ }^{2}$ Nilo Bazzoli ${ }^{1}$ Elizete Rizzo ${ }^{4}$ \\ Laércio dos Anjos Benjamin ${ }^{2 *}$
}

'Programa de Pós-graduação em Biologia de Vertebrados da PUC Minas, Pontifícia Universidade Católica de Minas Gerais (PUC Minas), Belo Horizonte, MG, Brasil.

2Departamento de Veterinária, Universidade Federal de Viçosa (UFV), 36.570-900, Viçosa, MG, Brasil. E-mail: laercio@ufv.br. *Corresponding author.

${ }^{3}$ Departamento de Biologia, Universidade do Estado de Minas Gerais (UEMG), Ibirité, MG, Brasil.

${ }^{4}$ Departamento de Morfologia, Universidade Federal de Minas Gerais (UFMG), Belo Horizonte, MG, Brasil.

ABSTRACT: Lambari, Astyanax bimaculatus, is an oviparous, multiple-spawning fish that is reproductively active throughout the year, which makes it promising for cultivation and research. This research histologically evaluates the ovaries of lambari that have undergone artificial spawning induced with pituitary extract (control group), and the effect of growth hormone at a dose of $2 \mu \mathrm{g} / \mathrm{g}$ body weight (treatment group) on the subsequent process of ovarian recovery. Ovaries of fish in both the control and treatments groups were collected at 120 hours after spawning and analyzed using optical microscopy to characterize the average quantities of: follicles in different stages of development, post-ovulatory follicles, follicular atresia and granulocytes. Quantity and morphology of early and advanced primary follicles did not differ between the treatment and control groups; an important and necessary factor for ovarian recovery for subsequent spawning. There was a greater amount of granulocytes in initial atresia in the group treated with growth hormone. These results demonstrated that the administration of growth hormone may potentiate the process of ovarian recovery after induced spawning.

Key words: atresia, granulocytes, post-ovulatory follicles, freshwater fishes.

Hormônio de crescimento sobre a morfologia ovariana de lambaris

(Astyanax bimaculatus) após desova induzida

\begin{abstract}
RESUMO: O Lambari Astyanax bimaculatus é um peixe ovíparo de desova múltipla que é reprodutivamente ativo durante todo o ano, o que o torna promissor para cultivo e pesquisa. Este trabalho avalia histologicamente os ovários de lambaris submetidos à desova artificial, induzida pelo extrato hipofisário (grupo controle) e o efeito do hormônio de crescimento na concentração de $2 \mu \mathrm{g} / \mathrm{g}$ de massa corporal (grupo tratamento) no subsequente processo de recuperação ovariana. Os ovários dos peixes dos grupos controle e tratamento foram coletados às 120 horas após a desova e analisados em microscopia óptica para caracterizar as quantidades médias de: folículos em diferentes estágios de desenvolvimento, folículos pós-ovulatórios, atresia folicular e granulócitos. A quantidade e a morfologia dos folículos primários iniciais e avançados não diferiram entre os grupos tratamento e controle; um fator importante e necessário para a recuperação dos ovários para posterior desova. Houve maior quantidade de granulócitos na atresia inicial no grupo tratado com hormônio de crescimento. Esses resultados demonstram que a administração do hormônio do crescimento pode potencializar o processo de recuperação ovariana após a desova induzida. Palavras-chave: atresia, granulócitos, folículos pós-ovulatórios, peixes de água doce.
\end{abstract}

\section{INTRODUCTION}

Lambari, Astyanax bimaculatus (Linnaeus, 1758), is a characiform fish of the family Characidae. Revisions have considered many of the 88 genera (620 species) of Characidae as "Incertaesedis", with 86 species belonging to the genus Astyanax (LIMA et al., 2003). Several papers have reported the importance of lambari to the trophic structure of Brazilian ecosystems and their reproductive behavior in the face of environmental change (PRADO et al., 2011; MARCON et al., 2015a). Lambari is of great importance to the equilibrium of the ecosystems where they occur, namely rivers of South and Central America, and they are well represented in such ecosystems in Brazilian (CARVALHO et al., 2009; WEBER et al., 2013). Astyanax bimaculatus is an omnivorous forager and a nutritionally important species for riverine communities (CARVALHO et al., 2009). 
The survival of any fish species depends on the production of viable eggs (GOMES et al., 2018). The main stages of follicular development in fish are, in general, the pre-meiotic, perinucleolar, vitellogenic, and final maturation periods (SELMAN \& WALLACE, 1989; GRIER, 2012). Impaired follicular development or atresia (LANG, 1981; MIRANDA et al., 1999) can be caused by stress, pesticides, temperature, hormones, light, inadequate nutrition, and confinement (NAGAHAMA, 1983; GURAYA, 1986). Follicular atresia can have serious effect on cultivation and induced spawning of fish, since this degenerative ovarian process lowers fertility rate (LAM, 1983). Post-ovulatory follicles are the remains of ovarian follicles that occur in fish ovaries after spawning (SELMAN \& WALLACE, 1989). These structures have been investigated in numerous teleosts, with some studies indicating that they are rapidly reabsorbed as follicular cells develop phagocytic activity (LINARES-CASENAVE et al., 2002).

Along with reduced stocks of natural fisheries, there is increasing need to develop technology for artificial reproduction of commercially high-value species in order to improve reproductive potential and the production of fingerlings for fish culture and reintroduction. Induced spawning of freshwater fish is usually performed using the method of hypophysation (WOYNAROVICH \& HORVÁTH, 1980; FORTUNY et al., 1998; LOKMAN et al., 2015), where crude carp (Cyprinus carpio) pituitary extract is injected into the coelomic cavity or within the muscle.

Studies on growth hormone in fish have addressed development and growth (BERN, 1983), reproduction (LE GAC et al., 1993), immune response (CALDUCH-GINER et al., 1997) and osmoregulation (SANGIAO-ALVARELLOS et al., 2006). Growth hormone $(\mathrm{GH})$ is a peptide of approximately $20 \mathrm{kDa}$ that is secreted by the pituitary gland of vertebrates (YAMAGUCHI et al., 1991). The GH coding region tends to be highly conserved among vertebrates, including mammals, birds, reptiles, amphibians and fish (MA et al., 2012), with a similar three-dimensional structure in different taxonomic groups and the same function in spite of varying amino acid sequences (CLACKSON et al., 1998). Growth hormone has great influence on growth rate and development by promoting cell division, differentiation and growth (CORIN et al., 1990; COPELAND \& NAIR, 1994). It is also involved in the metabolism of carbohydrates, lipids, proteins and nucleic acids (KLAUSEN et al., 2001).
In fish reproduction, growth hormone is related to significant increases in vitellogen in plasma level (HULL \& HARVEY, 2001), which are associated with gonadal maturation (HOLLOWAY et al., 1999), and thus plays a fundamental role in the development and maintenance of follicles. Understanding the effects of growth hormone in ovaries of $A$. bimaculatus can provide information that can help improve ovarian recovery prior to subsequent spawning. In this sense, the present study aimed to evaluate the effects of growth hormone, 120-hours after induced spawning, using histological and histometric techniques.

\section{MATERIALS AND METHODS}

\section{Fish and induced spawning}

During the month of February (summer), 200 female lambari (A. bimaculatus) in advanced maturation (mean total length $8: 49 \pm 1.31 \mathrm{~cm}$, mean body weight $10.19 \pm 4.47 \mathrm{~g}$ ) were obtained from Prata's Fish Farm (Eugenópolis, MG, 2105'56"S $\left.42^{\circ} 11^{\prime} 13^{\prime \prime} \mathrm{W}\right)$. The selected lambari were chosen based on aspects of their body, such as having a bulging belly or a dilated and vascularized genital pore. Fish were removed from their earthen ponds one day prior to hypophysation and transferred to masonry tanks $(1.50 \times 0.70 \times 0.40 \mathrm{~m})$, where they remained for the duration of the experimental period at temperature of $25 \pm 1{ }^{\circ} \mathrm{C}$. The fish were fed with a commercial diet containing $35 \%$ protein, twice daily. Fish were selected for an intra-coelomic doubledose of common carp (Cyprinus carpio) pituitary extract, with the first injection being a dose of 0.5 $\mathrm{mg} / \mathrm{kg}$ body weight (priming dose), and the second injection, 14 hours later, being a dose of $6 \mathrm{mg} / \mathrm{kg}$ (WOYNAROVICH \& HORVATH, 1980). After hypophysation, females were kept in the masonry tanks until the time of spawning. After spawning (120 females or $60 \%$ spawning at approximately nine hours after the second injection), as a result of the treatment with the double-dose of pituitary extract, the fish $(n=110)$ were divided into two groups: a control group $(n=55)$ and a $\mathrm{GH}$ treatment group $(n=55)$. Both groups were housed in masonry tanks with constant water circulation and a temperature of around $25 \pm 1{ }^{\circ} \mathrm{C}$.

\section{Treatments}

For the collection of ovaries, females of the control group $(n=55)$ were anesthetized with a 1:10,000 benzocaine solution and euthanized by transition stem head incision, in accordance with the 
ethical principles established by the Brazilian College of Animal Experimentation (COBEA, http://www. cobea.org.br). This study was submitted and approved by the Ethics Committee on Animal Use (Protocol no. 59/2005) of the Federal University of Viçosa (UFV). Ovaries were collected from the control group at 0 $(\mathrm{n}=5)$ and $120(\mathrm{n}=50)$ hours post spawning induction.

The treatment group $(n=55)$ was subjected to human growth hormone (Saizen ${ }^{\circledR}$, Serono) at a dose of $2 \mu \mathrm{g} / \mathrm{g}$ body weight (SEIDELIN \& MADSEN, 1999), which was administered intra-coelomically immediately after spawning induction. Ovaries were collected from the treatment group following the same procedures and timing adopted for the control group.

\section{Biometric parameters}

The following biometric data were recorded for each specimen: body weight (BW, $\mathrm{g}$ ), weight of ovaries (PO, g) and liver weight (FW, g). Mean values and standard deviations for the gonadosomatic (GSI=POx100/BW) and hepatosomatic $(\mathrm{HSI}=\mathrm{FWx} 100 / \mathrm{BW})$ indices were calculated for both groups 120 hours post-spawning.

\section{Morphological study}

All fish sacrificed in the experiment were used for morphological study of the ovaries. Fragments of the middle region of the ovaries were fixed for a minimum of 24 hours in $10 \%$ buffered formaldehyde (0.1 M phosphate buffer $\mathrm{pH} 7.2)$ and preserved in $70 \%$ ethanol (GODINHO et al., 2005). The fragments were then transferred to a $95 \%$ alcohol solution for four hours. Shortly thereafter, the fragments were immersed in $95 \%$ ethanol + glycolmethacrylate resin (Leica, Historesin) at a ratio of 1:1 for 12 hours followed by pure resin for 24 hours. Fragments were then sectioned at 1-3 $\mu \mathrm{m}$ thick and stained with hematoxylin-eosin and PAS/metanil-yellow. After staining, slides ovaries of both the control group and the treatment groupwere analyzed under a Olympus BX40 light microscope. Ten randomly-chosen fields of histological slides throughout the length of the ovary were examined using a $10 \mathrm{X}$ objective and a 40X objective, the latter for morphological analysis of the action of growth hormone by comparing ovarian tissue between groups. Digital images were obtained using an Olympus AX70 photomicroscope TRF, in the Laboratory of Plant Anatomy, Department of Vegetal Biology at the UFV.

\section{Histometric analysis}

Slides of 10 ovarian sections of each animal of both the control group $(n=55)$ and the treatment group $(n=55)$ were analyzed under an Olympus BX40 light microscope. Counts of developing ovarian follicles and atretic follicles were taken for each animal of both the control and treatment groups at 120 hours post-spawning. Counts of post-ovulatory follicles were taken at 0 and 120 hours after spawning to confirm the presence of post-ovulatory follicles. Counts for each section were done in 10 randomly selected fields for each animal in both groups using a microscope equipped with a micrometer reticle $(1 \mathrm{~mm})$ in a $10 \mathrm{X}$ objective. Granulocytes associated with atretic follicles were also counted in 10 randomly selected fields using a microscope with a $40 \mathrm{X}$ objective (MARCON et al., 2015a).

\section{Statistical analysis}

Data are reported as mean \pm standard deviation and were evaluated using the software Statistica 7.0. Quantitative variables were tested for homoscedasticity (Levenes) and normality (Shapiro-Wilk). Differences in the average number of follicles in different stages of development, post-ovulatory follicles, follicular atresia and the number of granulocytes between the control group and the treatment group were tested for significance using t-tests. When the assumptions of normality and homoscedasticity were not met, even after appropriate transformations, the data were subjected to the nonparametric Mann-Whitney test. In addition, interaction between cell type (granulocytes and total atresia) and groups (control and GH treatment) was assessed using two-factor ANOVA. Pearson's correlation was used to compare the proportion of granulocytes associated with total atretic follicles in the control group and the treatment group. The criterion for significance was $\mathrm{P}<0.05$. Graphics were produced using Microsoft Excel 2010 program.

\section{RESULTS}

The ovary of $A$. bimaculatus has the tunica albuginea emitting septa into the organ to form ovigerous lamellae, which are follicles in different developmental stages. The same pattern of follicular development was observed in both the control and treatment groups at 120 hours post-spawning (Figures $1 \mathrm{~A}-\mathrm{F}$ and $2 \mathrm{~A}$ ). Differences between initial, intermediate and advanced atresia are shown in figure 2. The presence of post-ovulatory follicles was also observed in both the control and treatment groups (Figures $1 \mathrm{~A}, \mathrm{~B}$ and $\mathrm{C}$ ).

Different stages of follicular development were quantified in both groups, but there were no 


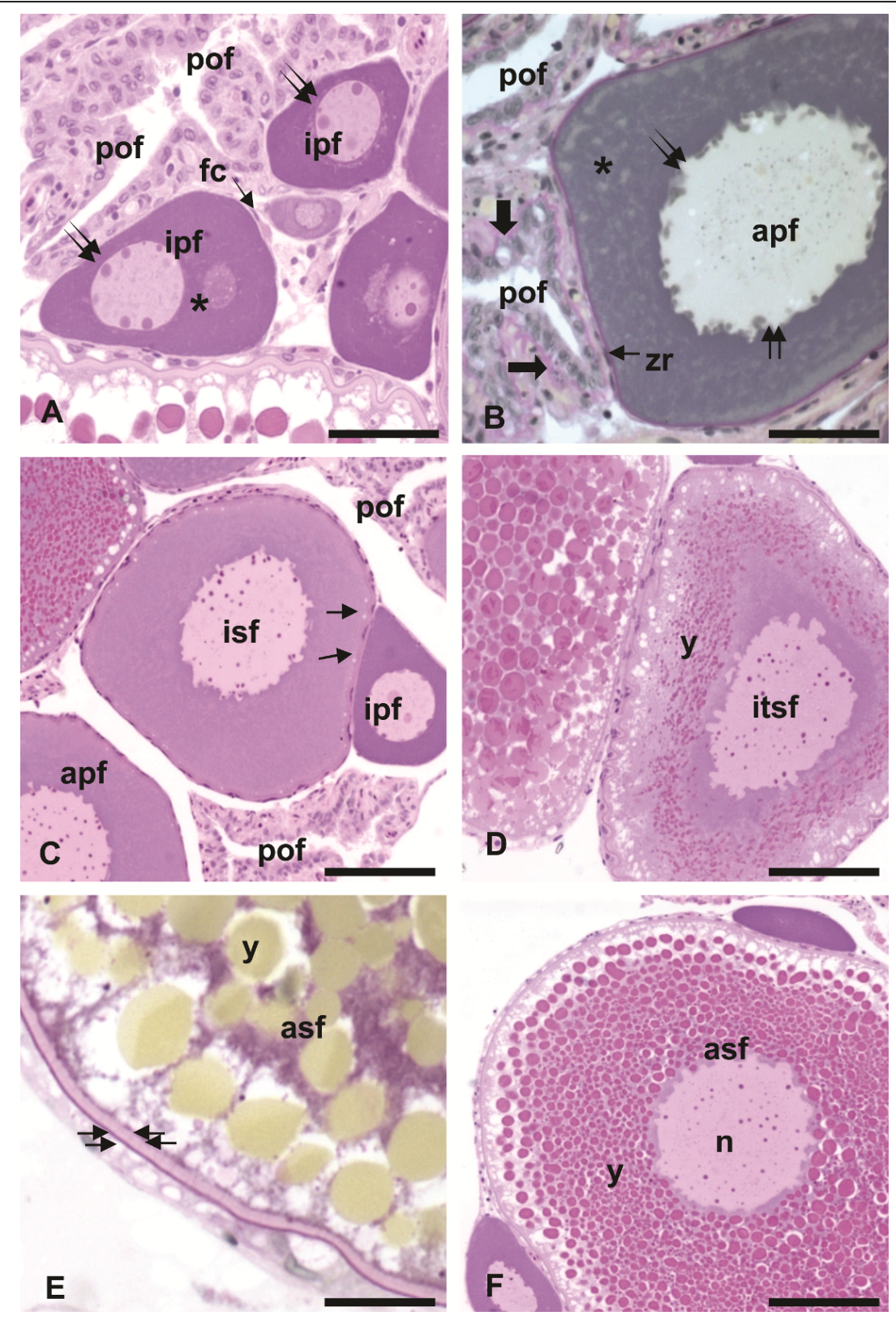

Figure 1 - Ovarian morphology of $A$. bimaculatus showing follicular development in the control and treatment (growth hormone - GH) groups at120 hours post-induced spawning. A (control group): Initial primary follicles (ipf). Follicular cell (fc) flattened surrounding the primary follicle, Balbiani bodies in the cytoplasm (asterisk) and envelope of the uniform nucleus (double arrow). B (treatment), C and D (control): Advanced primary follicles (apf) with cytoplasm showing granules (asterisk) and beginning to form a zona radiata (zr) PAS+. Envelope of the irregular nucleus (double arrow); in the initial secondary follicle (isf) formation of cortical vesicles begins (single arrow), while the intermediate secondary follicle (itsf) initiates the deposition of yolk globules (y) in the periphery of the cytoplasm. E (treatment) and F (control): In advanced secondary follicle (asf) the zona radiata (zr) consists of two layers PAS + (double arrow), filled with yolk globules (y) and an irregular nuclear envelope with nucleoli scattered throughout the nucleoplasm (n). Legend: post-ovulatory follicle (pof) having wall composed of single layer of follicular cells and basement membrane PAS+ (thick arrow) delineating a broad and irregular lumen. Staining: hematoxylin-eosin (Figures A, C, D and F); PAS/ metanil-yellow (Figures B and E). Bars: A, B and E $(50 \mu \mathrm{m})$; C, D and F (100 $\mu \mathrm{m})$. 


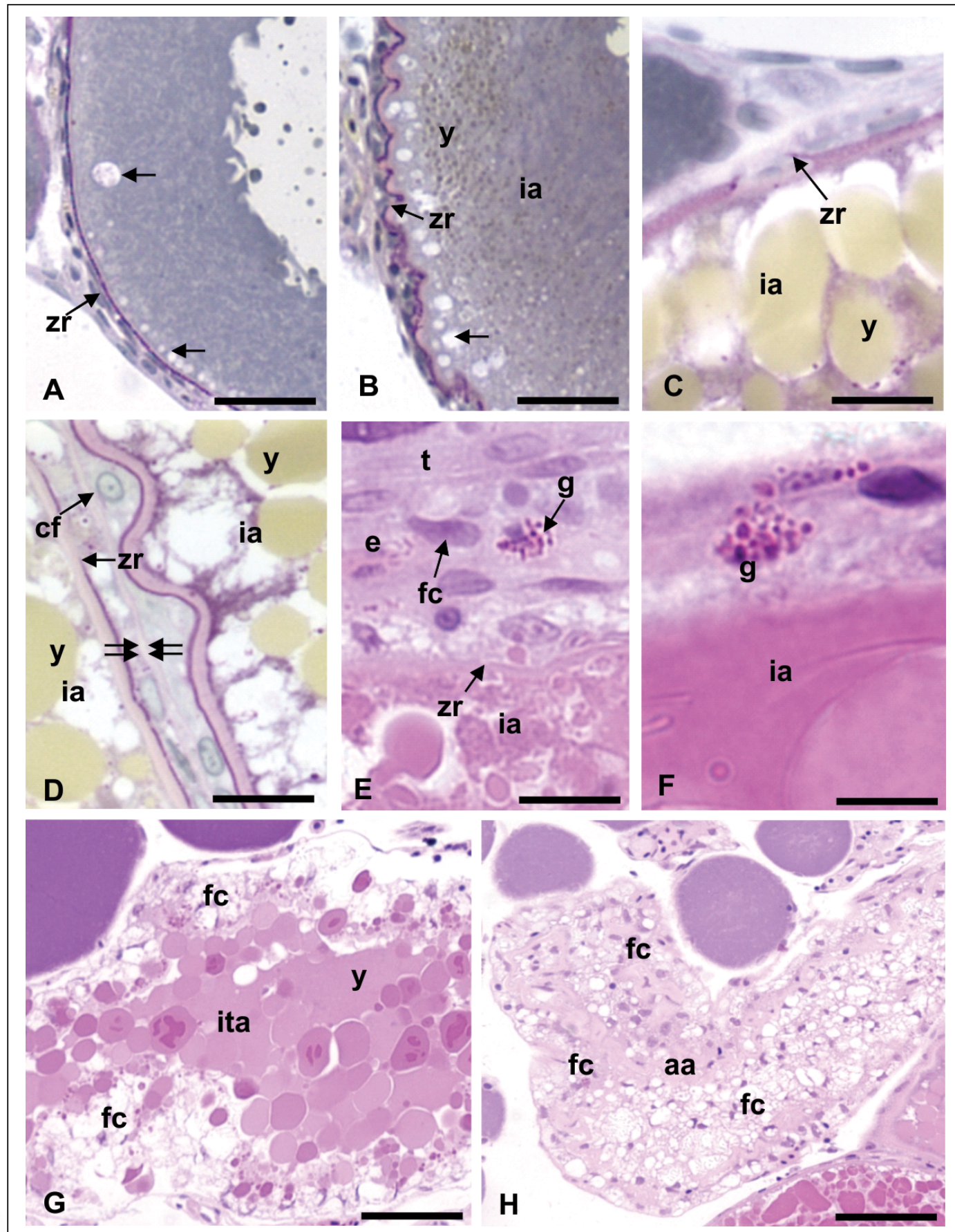

Figure 2 - Ovarian morphology of $A$. bimaculatus showing follicular atresia in the control and treatment (growth hormone - GH) groups at 120 hours post-induced spawning. A (control): initial secondary follicles (isf) having normal characteristics with cortical vesicle (single arrow) at the periphery of the cytoplasm and zona radiata (zr). B, C (control), D (treatment): In initial atresia (ia) can be seen discontinuities and breaks of the zona radiata (zr) marked by PAS +/metanil-yellow. E (control) and F (treatment): Hypertrophy of follicular cells (fc) and granulocyte $(\mathrm{g})$ associated with the atretic follicle. G (control): Intermediate atresia (ita) showing liquefying of the yolk globules (y) and follicular cells (fc) invading the cytoplasm of the follicle. H (control): In advanced atresia (aa), follicular cells (fc) phagocytize the final residues of the follicle, leading to a decrease in the size of the atretic follicles. Legend: fc- follicular cell; t- squamous theca cells; double arrow - basement membrane; y- yolk globules; e- erythrocytes. Staining: PAS/metanil-yellow (A, B, C and D) and hematoxylin-eosin (E, F, G and H). Bars: A $(80 \mu \mathrm{m}) ; \mathrm{B}(30 \mu \mathrm{m}) ; \mathrm{C}, \mathrm{D}$ and E $(15 \mu \mathrm{m}) ; \mathrm{F}(8 \mu \mathrm{m}) ; \mathrm{G}(40 \mu \mathrm{m}) ; \mathrm{H}(70 \mu \mathrm{m})$ 
significant differences (control group: $\mathrm{ipf}=5.66 \pm$ 1.54; apf $=2.61 \pm 1.04 ;$ isf $=0.64 \pm 0.30 ;$ itsf $=0.70$ \pm 0.30 ; asf $=2.60 \pm 0.70$; treatment group: $\mathrm{ipf}=4,50$ $\pm 1.18 ;$ apf $=2,31 \pm 0.55 ;$ isf $=0,79 \pm 0.32 ;$ itsf $=0.96$ \pm 0.38 ; asf $=3.12 \pm 0.52)($ Figure 3$)$. The treatment group $(0=5.49 \pm 1.5 ; 120=1.49 \pm 1.04)$ and the control group $(0=5.10 \pm 1.2 ; 120=2.29 \pm 1.79) \mathrm{did}$ not differ significantly in post-ovulatory follicles at 0 hours and 120 hours. The number of post-ovulatory follicles differed significantly between the collections made at 0 hours and 120 hours.

Counts of follicles in initial atresia were greater $(\mathrm{P}<0.05)$ in the treatment group (initial atresial $=0.50 \pm 0.37$; intermediate atresia $=0.16 \pm$ 0.09 ; advanced atresia $=0.06 \pm 0.04$; total atresia $=$ $0.72 \pm 0.20$ ) than in the control group (initial atresial= $0.14 \pm 0.11$; intermediate atresia $=0.21 \pm 0.16$; advanced atresia $=0.13 \pm 0.09$; total atresia $=0.48 \pm$ 0.04 ) at 120 hours (Figure 4). There was a greater number of granulocytes $(\mathrm{P}<0.05)$ in the treatment group (granulocytes $=6.49 \pm 2.64$; total atresia $=0.72$ \pm 0.20 ) than in the control group (granulocytes $=$ $2.77 \pm 1.92$; total atresia $=0.48 \pm 0.04)$ (Figure 5). There was a significant interaction $(\mathrm{P}<0.05)$ between cell type (granulocytes and total atresia) and group (control and GH treatment). A positive correlation $(\mathrm{r}=0.68)$ was detected between in proportion of granulocytes associated with total atretic follicles in both the control and treatment groups during the experimental period.

The GSI did not differ significantly between the treatment group $(6.47 \pm 1.77)$ and the control group $(5.93 \pm 1.97)$ for 120 hours. Likewise, IHS did not differ significantly between the treatment group $(3.32 \pm 2.09)$ and the control group $(2.07 \pm 1.36)$ during the experimental period.

\section{DISCUSSION}

The present study found no morphological differences between the control and the treatment groups for the different stages of follicular development, confirming the pattern of follicular development typical of incertaesedis fish of the family Characidae (MARTINS et al., 2012; MARCON et al., 2017). More primary follicles were reported in the control group than in the treatment group; although, the difference was not significant. Nonetheless, these follicles are likely to be

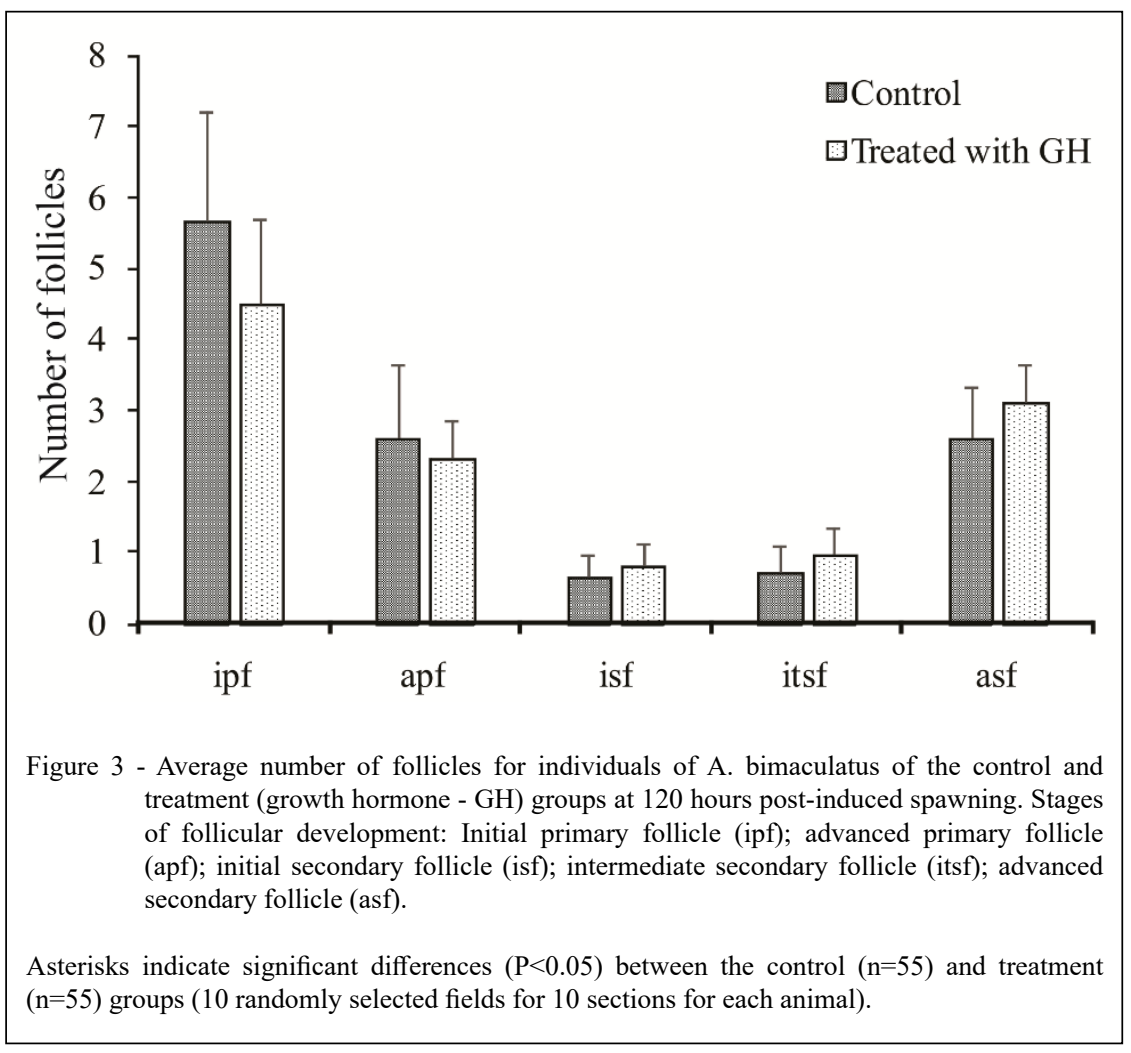

Ciência Rural, v.49, n.8, 2019. 


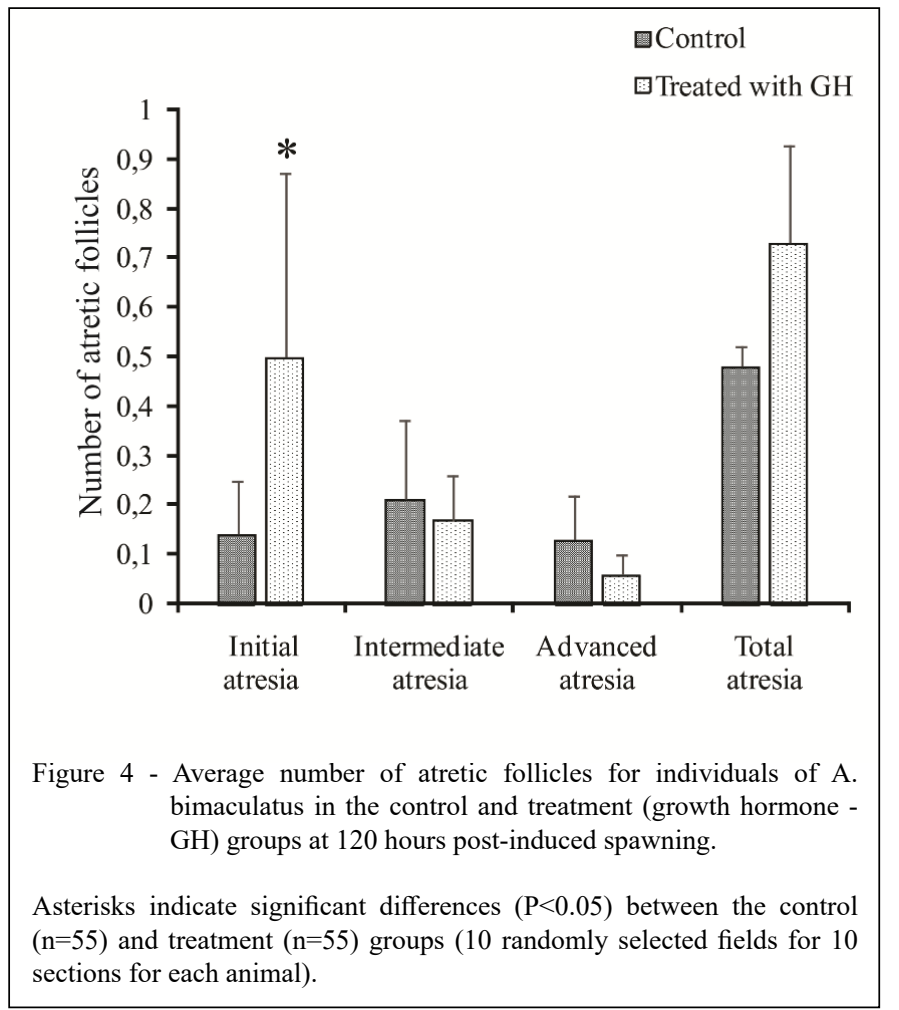

important for future spawns. These findings indicated that the use of growth hormone at the concentration applied was not sufficient for producing a greater amount of secondary follicles. An explanation for this finding is that growth hormone alone is not able to increase levels of vitellogenin. Conversely, when using growth hormone $+17 \beta$-estradiol (E2), growth hormone was able to potentiate the action of E2 by increasing the production of vitellogenin (PEYON et al., 1996), and thus is an important precursor in the recruitment of new follicles (COWARD \& BROMAGE, 1998). Thus, female $A$. bimaculatus treated with growth hormone did not respond significantly with the formation of new advanced and primary follicles, nor secondary follicles, during 120 hours post induced spawning.

The number of post-ovulatory follicles in each of the groups of the present study was similar to the number previously reported for Tilapia zilli and for $A$. bimaculatus, which exhibited a reduced number of post-ovulatory follicles and an occluded lumen on the third day post induced spawning (COWARD \& BROMAGE, 1998; DRUMMOND et al., 2000). These results indicated rapid reabsorption of postovulatory follicles. According to DRUMMOND et al. (2000), total resorption of post-ovulatory follicles in A. bimaculatus occurs in 13 days, and apoptosis of the follicular cells could be observed after the onset of the post-ovulatory period, as indicated by having a nucleus with a crescent pattern of chromatin condensation underlying the nuclear envelope and apoptotic bodies at different stages of reabsorption. During the involution of the post-ovulatory follicles of $A$. bimaculatus in the present study, there was a loss of contact between the membranes of adjacent follicular cells. This event was also reported by SANTOS et al. (2005) between 48 and 72 hours postspawning in Leporinustaeniatus. This loss of contact between adjacent follicular cells is an important factor during the involution of post-ovulatory follicles (GRIER, 2012), and was observed in the present research using the histochemical technique of PAS/metanil-yellow. Neither the control group nor the treatment of the present study exhibited complete elimination of post-ovulatory follicles during the post-spawning period of 120 hours.

The process of atresia has been studied by several authors, and is divided into several stages (SANTOS etal., 2005; SANTOS et al., 2008; MORAIS et al., 2012). The stage of initial atresia is characterized by follicular cell hypertrophy and breaking of the zona radiata, thereby allowing cell to be invaded by phagocytes, which consume the vitellogenic 


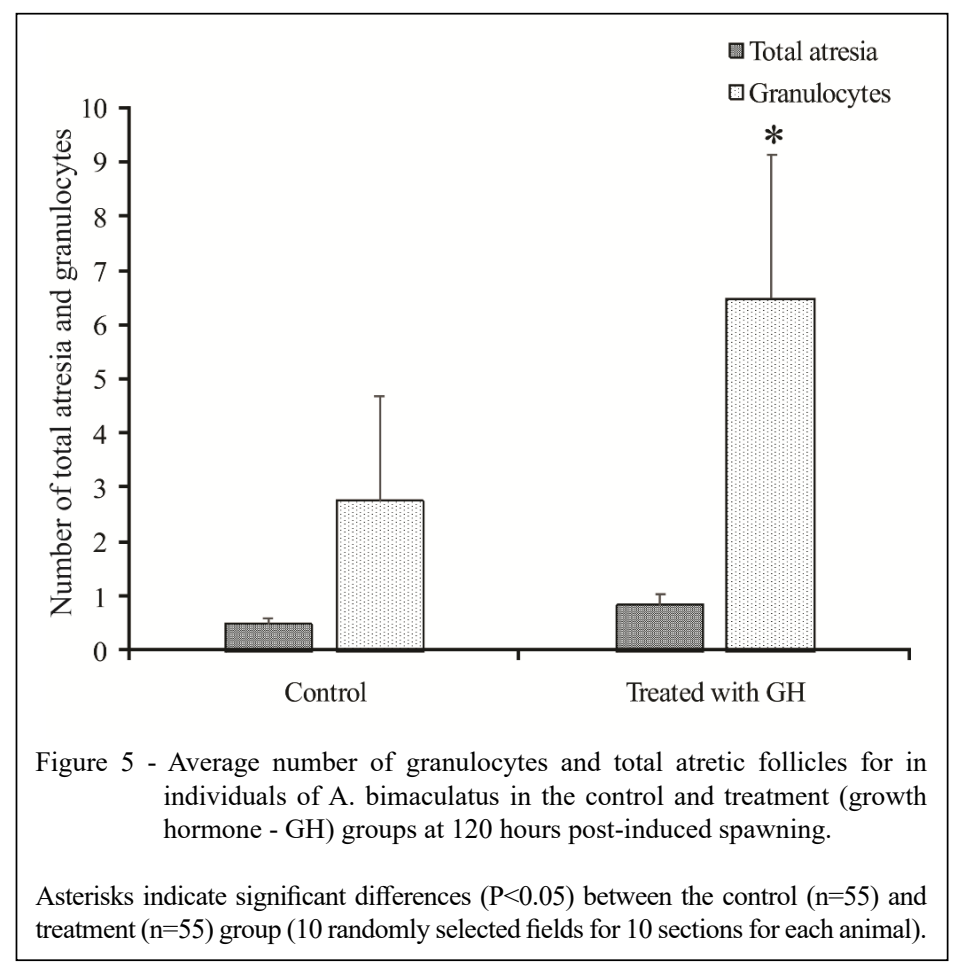

contents of the follicle (LINARES-CASENAVE et al., 2002). The degeneration and resorption of atretic follicles is a prolonged process, lasting up to seven months in $A$. bimaculatus, and frequently leaves signs in the ovary that can remain throughout the next reproductive cycle (MIRANDA et al., 1999). Ovarian regression was monitored for only 120 hours in the present study, but initial atretic follicles were very active during this period. Furthermore, granulocytes were observed infiltrating the theca and, according to these authors, they can participate in follicular resorption. This is consistent with the findings of the present study with $A$. bimacultaus, which had higher frequencies of granulocytes associated with total atretic follicles in the treatment group. These observations indicated that growth hormone may potentialize the recruitment of granulocytes in immunological processes (CALDUCH-GINER et al., 1997), and thus is important in initial atresia.

The IGS and IHS are indicators of the biological status of fish and are used to determine reproductive stage (HONJI et al., 2009; BONCOMPAGNI et al., 2013; DURHAM \& WILDE, 2014), because the maturation of primary and secondary follicles is concomitant with an increase in gonad weight and decreased liver weight in the final stages of the reproductive period (NORMANDO et al., 2014; PERINI et al., 2013). The absence of significant differences in IGS and IHS between the control group and the treatment group can be attributed to the fact that the experiment was short and reproduction was fast, as seen in the work by BUGEL et al. (2010) and MARCON et al. (2015b).

\section{CONCLUSION}

The administration of growth hormone after induced spawning increases the amount of granulocytes in ovaries after 120 hours. Granulocytes may be involved in tissue remodeling by removing initial atretic follicles, which may facilitate the process of ovarian recovery and follicular development for future spawning. In fact, it remains to be determined whether the observed response is more pronounced for periods longer than 120 hours. This research provides details of initial ovarian recovery for the 120 -hour post-spawn period, and thus contributes to understanding of ovarian structure.

\section{ACKNOWLEDGEMENTS}

This work was funded by the Fundação de Amparo à Pesquisa do Estado de Minas Gerais (FAPEMIG). We would also like to thank the Coordenação de Aperfeiçoamento de Pessoal de Nível Superior (CAPES). This study was conducted with funds granted by FAPEMIG (EDT 215/2005). 


\section{DECLARATION OF CONFLICT OF INTERESTS}

The authors declare no conflict of interest. The founding sponsors had no role in the design of the study; in the collection, analyses, or interpretation of data; in the writing of the manuscript, and in the decision to publish the results.

\section{AUTHORS' CONTRIBUTIONS}

$\mathrm{LM}$ and $\mathrm{LAB}$ conceived and designed experiments LM and LAB performed the experiments, LM, NB, ER and VRF carried out the lab analyses. LAB supervised and coordinated the animal experiments and provided clinical data. LM performed statistical analyses of experimental data. LM, LAB and NB prepared the draft of the manuscript. All authors critically revised the manuscript and approved of the final version.

\section{REFERENCES}

BERN, H. A. Functional evolution of prolactin and growthhormone in lower-vertebrates. American Zoologist, v.23, n.3, p.663-671, 1983. Available from: <https://www.jstor.org/ stable/3882948?seq=1\#page_scan_tab_contents $>$. Accessed: May, 13,2018 .

BONCOMPAGNI, O., et al. Reproductive biology of Prochilodus argenteus Agassiz, 1829 (Pisces: Prochilodontidae) in Sao Francisco River, Brazil. Journal of Applied Ichthyology, v.29, n.1, p.132-138, 2013. Available from: <https://onlinelibrary.wiley. com/doi/abs/10.1111/jai.12018>. Accessed: May, 14, 2018. doi: 10.1111/jai.12018

BUGEL, S. M., et al. Impaired reproductive health of killifish (Fundulus heteroclitus) inhabiting Newark Bay, NJ, a chronically contaminated estuary. Aquatic Toxicology, v.96, n.3, p.182193, 2010. Available from: <https:/www.ncbi.nlm.nih.gov/ pubmed/20079544>. Accessed: May, 14, 2018. doi: 10.1016/j. aquatox.2009.10.016.

CALDUCH-GINER, J. A., et al. Growth hormone as an in vitro phagocyte-activating factor in the gilthead sea bream (Sparus aurata). Cell and Tissue Research, v.287, n.3, p.535-540, 1997. Available from: <https://link.springer.com/article/10.1007/ s004410050777>. Accessed: May, 14, 2018. doi: 10.1007/ s004410050.

CARVALHO, P. A., et al. Reproductive biology of Astyanax fasciatus (Pisces: Characiformes) in a reservoir in southeastern Brazil. Journal Applied Ichthyology, v.25, n.3, p.306-313, 2009. Available from: $<$ https://onlinelibrary.wiley.com/doi/abs/10 $.1111 /$ j.1439-0426.2009.01238.x>. Accessed: May, 14, 2018. doi: 10.1111/j.1439-0426.2009.01238.x

CLACKSON, T., et al. Structural and functional analysis of the 1:1 growth hormone:receptor complex reveals the molecular basis for receptor affinity. Journal of Molecular Biology, v.277, n.5, p.1111-1128, 1998. Available from: <https://www.ncbi.nlm.nih. gov/pubmed/9571026>. Accessed: Oct. 30, 2018. doi: 10.1006/ jmbi.1998.1669.

COPELAND, K. C., \& NAIR. Acute growth-hormone effects on amino-acid and lipid-metabolism. The Journal of Clinical Endocrinology \& Metabolism, v.78, n.5, p.1040-
1047, 1994. Available from: <https://www.ncbi.nlm.nih.gov/ pubmed/8175957>. Accessed: May, 14, 2018. doi: 10.1210/ jcem.78.5.8175957.

CORIN, R. E., et al. Growth-hormone and adipose differentiation - growth hormone-induced antimitogenic state in 3t3-F442a preadipose cells. Proceedings of the National Academy of Sciences, v.87, n.19, p.7507-7511, 1990. Available from: <https:// www.ncbi.nlm.nih.gov/Pubmed/2217181>. Accessed: May, 14, 2018. doi: 10.1073/pnas.87.19.7507.

COWARD, K., \& BROMAGE, N. R. Histological classification of oocyte growth and the dynamics of ovarian recrudescence in Tilapia zillii. Journal of Fish Biology, v.53, n.1, p.285-302, 1998. Available from: <https://onlinelibrary.wiley.com/doi/ abs/10.1111/j.1095-8649.1998.tb00981.x>. Accessed: May, 14, 2018. doi: 10.1111/j.1095-8649.1998.tb00981.x.

DRUMMOND, C. D., et al. Postovulatory follicle: a model for experimental studies of programmed cell death or apoptosis in teleosts. Journal of Experimental Zoology, v.287, n.1, p.176-182, 2000. Available from: <https://www.ncbi.nlm. nih.gov/pubmed/10900437>. Accessed: May, 14, 2018. doi: 10.1002/1097-010X(20000701)287:2<176::AID-JEZ8>3.0.CO;2-2.

DURHAM, B., \&WILDE, G. Understanding complex reproductive ecology in fishes: the importance of individual and population-scale information. Aquatic Ecology, v.48, n.1, p.91-106, 2014. Available from: <https://link.springer.com/article/10.1007/s10452-014-94690>. Accessed: May, 14, 2018. doi: 10.1007/s10452-014-9469-0.

FORTUNY, A., et al. Hormonal induction of final maturation and ovulation in the sábalo, Prochilodus platensis Holmberg: treatments, latency and incubation times and viability of ovules retained in the ovary after ovulation. Aquaculture, v.73, n.1-4, p.373-381, 1998. Available from: $<$ https://www.sciencedirect.com/ science/article/pii/0044848688900701>. Accessed: May, 14, 2018. doi: 10.1016/0044-8486(88)90070-1.

GODINHO, H. P., et al. Gonadal features and reproductive traits of the Amazonian fish Arapaima gigas (Schinz 1822). Acta Zoologica (Stockholm), v.86, n.4, p.289-294, 2005. Available from: <https://onlinelibrary.wiley.com/doi/abs/10.11 11/j.1463-6395.2005.00213.x>. Accessed: May, 14, 2018. doi: 10.1111/j.1463-6395.2005.00213.x.

GOMES, R. Z.,et al. Early development of Brycon orthotaenia (Pisces: Characidae). Zygote, v.21, n.1, p.11-20, 2013. Available from: $<$ https://www.ncbi.nlm.nih.gov/pubmed/21733293>. Accessed: May, 14, 2018. doi: 10.1017/S0967199411000311.

GRIER, H. J. Development of the follicle complex and oocyte staging in red drum, Sciaenops ocellatus Linnaeus, 1776 (Perciformes, Sciaenidae). Journal of Morphology, v.273, n.8, p.801-829, 2012. Available from: <https://www.ncbi.nlm.nih. gov/pubmed/22707292>. Accessed: May, 14, 2018. doi: 10.1002/ jmor.20034.

GURAYA, S. S. The cell and molecular biology of fish oogenesis Monographs in Developmental Biology, Karger, Basel, vol. 18, p.1-223, 1986.

HONJI, R. M., et al. Patterns of oocyte development in natural habitat and captive Salminus hilarii Valenciennes, 1850 (Teleostei: Characidae). Fish Physiology and Biochemistry, v.35, n.1, p.109-123, 2009. Available from: <https://www.ncbi.nlm.nih. 
gov/pubmed/19189238>. Accessed: May, 14, 2018. doi: 10.1007/ s10695-008-9239-9.

HULL K. L., \& HARVEY, S. Growth hormone: roles in female reproduction. The Journal of endocrinology, v.168, n.1, p.123, 2001. Available from: <https:/www.ncbi.nlm.nih.gov/ pubmed/11139766>. Accessed: Oct. 30, 2018.

HOLLOWAY, A. C., et al.Correlations of plasma growth hormone with somatostatin, gonadal steroid hormones and thyroid hormones in rainbow trout during sexual recrudescence. Comparative Biochemistry and Physiology Part B: Biochemistry and Molecular Biology, v.123, n.3, p.251-260, 1999. Available from: $<$ https://www.ncbi.nlm.nih.gov/pubmed/10481254>. Accessed: Oct. 17,2018

KLAUSEN, C., et al. The effect of gonadotropin-releasing hormone on growth hormone and gonadotropin subunit gene expression in the pituitary of goldfish, Carassius auratus. Comparative Biochemistry and Physiology Part B: Biochemistry and Molecular Biology, v.129, n.2-3, p.511-516, 2001. Available from $<$ https://www.ncbi.nlm.nih.gov/pubmed/11399486>. Accessed: May, 14, 2018. doi: 10.1016/S1096-4959(01)00351-7.

LAM, T. J. Environmental influences on gonadal activity in fish. In: Hoar, W.S., Randall, D.J., Donaldson, E.M. (eds). Fish Physiology. Academic Press, London, 1983, v.9, p.65-116. Available from: <https://www.sciencedirect.com/science/article/ pii/S1546509808603027>. Accessed: Oct. 17, 2018. doi: 10.1016/ S1546-5098(08)60302-7.

LANG, I. Electron microscopic and histochemical investigations of the atretic oocyte of Perca fluviatilis L. (Teleostei). Cell and Tissue Research, v.220, n.1, p.201-212, 1981. Available from: $<$ https://www.ncbi.nlm.nih.gov/pubmed/6456070>. Accessed: Oct. 30,2018 .

LE GAC, F., et al. Growth hormone $(\mathrm{GH})$ and reproduction: a review. Fish Physiology and Biochemistry, v.11, n. 1-6, p.219232, 1993. Available from: <https:/www.ncbi.nlm.nih.gov/ pubmed/24202479>. Accessed: May, 14, 2018. doi: 10.1007/ BF00004569.

LIMA, F. C. T., et al. Genera Incertae Sedis in Characidae. P. 106-169. In: Reis, R. E., S. O. Kullander,and C. J. Ferraris, (Orgs.) Check list of the freshwater fishes of South and Central America. Porto Alegre: EDIPUCRS. p 729, 2003.

LINARES-CASENAVE, J., et al. Ultrastructural and histological observations on temperature-induced follicular ovarian atresia in the white sturgeon. Journal of Applied Ichthyology, n.4-6, v.18, p.382-390, 2002. Available from: $<$ https://onlinelibrary.wiley.com/ doi/abs/10.1046/j.1439-0426.2002.00369.x>. Accessed: May, 14, 2018. doi: 10.1046/j.1439-0426.2002.00369.x.

LOKMAN, P. M., et al. Artificial induction of maturation in female silver eels, Anguilla australis: The benefits of androgen pretreatment. Aquaculture, v.437, n.1, p.111-119, 2015. Available from: $\quad<$ https://www.sciencedirect.com/science/article/pii/ S0044848614006000>. Accessed: May, 14, 2018. doi: 10.1016/j. aquaculture.2014.11.026.

MA, Q., et al. Genomic structure, polymorphism and expression analysis of the growth hormone (GH) gene in female and male Half-smooth tongue sole (Cynoglossus semilaevis). Gene, v.493, n.1, p.92-104, 2012. Available from: <https:/www.sciencedirect.
com/science/article/pii/S0378111911006858>. Accessed: Oct. 30, 2018. doi: 10.1016/j.gene.201111.015.

MARCON, L., et al. Immunohistochemical, morphological and histometrical analyses of follicular development in Astyanax bimaculatus (Teleostei: Characidae) exposed to an organochlorine insecticide. Ecotoxicology and Environmental Safety, v.143, n.1, p.249-258, 2017. Available from: <https:/www.sciencedirect. com/science/article/pii/S014765131730307X?via\%3Dihub>. Accessed: May, 14, 2018. doi: 10.1016/j.ecoenv.2017.05.029.

MARCON, L., et al. Histological and Histometric Evaluation of the Liver in Astyanax bimaculatus (Teleostei: Characidae), Exposed to Different Concentrations of an Organochlorine Insecticide. The Anatomical Record, v.298, n.10, p.1754-1764, 2015a. Available from: <https://onlinelibrary.wiley.com/doi/abs/10.1002/ar.23196>. Accessed: May, 14, 2018. doi: 10.1002/ar.23196.

MARCON, L., et al. Effects of insecticide Thiodan ${ }^{\circledR}$ on the morphology and quantification of ovarian follicles in lambaris Astyanax bimaculatus (Linnaeus, 1758) in different treatments. Aquaculture Research, v.47, n.8, p.2407-2418, 2015b. Available from: <https://onlinelibrary.wiley.com/doi/abs/10.1111/ are.12687>. Accessed: May, 14, 2018. doi: 10.1111/are.12687.

MARTINS, Y. S., et al. Comparative analysis of gonadal morphology in six fish species of the Incertae Sedis genera in Characidae of occurrence in the São Francisco River Basin, Brazil. Acta Zoologica, v.93, n.1, p.48-56, 2012. Available from: $<\mathrm{https}$ :// onlinelibrary.wiley.com/doi/full/10.1111/j.1463-6395.2010.00478. $\mathrm{x}>$. Accessed: May, 14, 2018. doi: 10.1111/j.14636395.2010.00478.x

MIRANDA, A. C., et al. Ovarian follicular atresia in two teleost species: a histological and ultrastructural study. Tissue and Cell, v.31, n.5, p.480-488, 1999. Available from: <https://www.ncbi. nlm.nih.gov/pubmed/18627868>. Accessed: May, 14, 2018. doi: 10.1054/tice.1999.0045

MORAIS, R. D., et al. Autophagy and apoptosis interplay during follicular atresia in fish ovary: a morphological and immunocytochemical study. Cell and Tissue Research, v.347, n.2, p.467-478, 2012. Available from: $<$ https://www.ncbi.nlm.nih. gov/pubmed/22314847>. Accessed: May, 14, 2018. doi: 10.1007/ s00441-012-1327-6

NAGAHAMA, Y. The functional morphology of teleost gonads. In: Hoar, W.S., Randall, D.J., Donaldson, E.M. (eds). Fish Physiology. Academic Press, London, v.9, p.233-275, 1983. Available from: $<$ https://www.sciencedirect.com/science/article/ pii/S1546509808602903>. Accessed: Oct. 30, 2018. doi: 10.1016/ S1546-5098(08)60290-3.

NORMANDO, F., et al. Impact of the Três Marias dam on the reproduction of the forage fish Astyanax bimaculatus and $A$. fasciatus from the São Francisco River, downstream from the dam, southeastern Brazil. Environmental Biology of Fishes, v.97, n.3, p.309-319, 2014. Available from: <https://link.springer.com/ article/10.1007/s10641-013-0153-3>. Accessed: May, 14, 2018. doi: $10.1007 / \mathrm{s} 10641-013-0153-3$.

PERINI, V. R., et al. Comparative analysis of the oocytes and early development of two species of curimatidae teleost fish. Anatomia, Histologia, Embryologia, v.42, n.1, p.40-47, 2013. Available from: $<$ https://www.ncbi.nlm.nih.gov/pubmed/22583005>. Accessed: May, 14, 2018. doi: 10.1111/j.1439-0264.2012.01162.x. 
PEYON, P., et al. Potentiating effect of growth hormone on vitellogenin synthesis induced by 17 beta-estradiol in primary culture of female silver eel (Anguilla anguilla L.) hepatocytes. General and Comparative Endocrinology, v.102, n.2, p.263-273, 1996. Available from: <https://www.ncbi.nlm.nih.gov/pubmed/8998971>. Accessed: May, 14, 2018. doi: 10.1006/gcen.1996.0068.

PRADO, P. et al., Reproductive disruption in lambari Astyanax fasciatus from a Southeastern Brazilian reservoir. Ecotoxicology and Environmental Safety, v.74, n.7, p.18791887, 2011. Available from: <https://www.ncbi.nlm.nih.gov/ pubmed/21831433>. Accessed: May, 14, 2018. doi: 10.1016/j. ecoenv.2011.07.017.

SANGIAO-ALVARELLOS, S., et al. Growth hormone and prolactin actions on osmoregulation and energy metabolism of gilthead sea bream (Sparus auratus). Comparative Biochemistry and Physiology - Part A, v.144, n.4, p.491-500, 2006. Available from: $<$ https://www.ncbi.nlm.nih.gov/pubmed/16750408>. Accessed: May, 14, 2018. doi: 10.1016/j.cbpa.2006.04.015.

SANTOS, H. B., et al. Ovarian regression and apoptosis in the South American teleost Leporinus taeniatus Lutken (Characiformes, Anostomidae) from the Sao Francisco Basin. Journal of Fish Biology, v.67, n.5, p.1446-1459, 2005. Available from: $<$ https://onlinelibrary. wiley.com/doi/abs/10.1111/j.1095-8649.2005.00854.x>. Accessed: May, 14, 2018. doi: 10.1111/j.1095-8649.2005.00854.x.

SANTOS, H. B., et al. Ovarian follicular atresia is mediated by heterophagy, autophagy, and apoptosis in Prochilodus argenteus and Leporinus taeniatus (Teleostei: Characiformes) Theriogenology, v.70, n.9, p.1449-1460, 2008. Available from:
$<$ https://www.ncbi.nlm.nih.gov/pubmed/18701155>. Accessed: May, 14, 2018. doi: 10.1016/j.theriogenology.2008.06.09.

SEIDELIN, M., \& MADSEN, S. S. Endocrine control of $\mathrm{Na}+, \mathrm{K}+-$ ATPase and chloride cell development in brown trout (Salmo trutta): interaction of insulin-like growth factor-I with prolactin and growth hormone. Journal of Endocrinology, v.162, n.1, p.127-135, 1999. Available from: <https://www.ncbi.nlm.nih.gov/pubmed/10396029>. Accessed: May, 14, 2018. doi: 0022-0795/99/0162-0127.

SELMAN, K., \& WALLACE, A. R. Cellular aspects of oocyte growth in teleosts. Zoological science, v.6, p.211-231, 1989. Available from: $<$ https://www.biodiversitylibrary.org/part/71695\#/ summary>. Accessed: Oct. 30, 2018.

WEBER, A. A., et al. Oocyte adhesiveness and embryonic development of Astyanax bimaculatus (Linnaeus, 1758) (Pisces: Characidae). Zygote, v.21, n.2, p.198-202, 2013. Available from: $<$ https://www.ncbi.nlm.nih.gov/pubmed/22717095>. Accessed: May, 14, 2018. doi: 10.1017/S096719941200007X.

WOYNAROVICH, E., \& HORVÁTH, L. The artificial propagation of warm-water finfishes - a manual for extension. FAO Fish Technical Paper, n.201, p.183, 1980. Available from: <http://www.fao.org/ docrep/005/AC742E/AC742E00.HTM>. Accessed: May, 14, 2018.

YAMAGUCHI, K., et al. Amino acid sequence of growth hormone isolated from medium of incubated pituitary-glands of tilapia (Oreochromis-Mossambicus). General and Comparative Endocrinology, v.81, n.2, p.323-331, 1991. Available from: $<$ https://www.ncbi.nlm.nih.gov/pubmed/2019405>. Accessed: May, 14, 2018. doi: 10.1016/0016-6480(91)90017-Z. 